\title{
Pathogenic and Non-Pathogenic Fungal Communities in Wheat Grain as Influenced by Recycled Phosphorus Fertilizers: A Case Study
}

\author{
Magdalena Jastrzębska $^{1, *(D)}$, Urszula Wachowska ${ }^{2}$ and Marta K. Kostrzewska ${ }^{1}$ \\ 1 Department of Agroecosystems, Faculty of Environmental Management and Agriculture, University of \\ Warmia and Mazury in Olsztyn, Plac Łódzki 3, 10-718 Olsztyn, Poland; marta.kostrzewska@uwm.edu.pl \\ 2 Department of Entomology, Phytopathology and Molecular Diagnostics, University of Warmia and Mazury \\ in Olsztyn, 10-721 Olsztyn, Poland; urszula.wachowska@uwm.edu.pl \\ * Correspondence: jama@uwm.edu.pl
}

Received: 23 April 2020; Accepted: 17 June 2020; Published: 19 June 2020

\begin{abstract}
Waste-based fertilizers provide an alternative to fertilizers made from non-renewable phosphate rock. Fungal communities colonizing the grain of spring wheat fertilized with preparation from sewage sludge ash and dried animal blood (Rec) and the same fertilizer activated by Bacillus megaterium (Bio) were evaluated against those resulting from superphosphate (SP) and no phosphorus (control, C0) treatments. The Illumina MiSeq sequencing system helped to group fungal communities into three clades. Clade 1 (communities from C0, Bio 60 and 80, Rec 80 and SP $40 \mathrm{~kg} \mathrm{P}_{2} \mathrm{O}_{5} \mathrm{ha}^{-1}$ treatments) was characterized by a high prevalence of Alternaria infectoria, Monographella nivalis and Gibberella tricincta pathogens. Clade 2 (Bio $40 \mathrm{~kg}$, $\mathrm{Rec} 40$ and $60 \mathrm{~kg}$, and SP $60 \mathrm{~kg} \mathrm{P}_{2} \mathrm{O}_{5} \mathrm{ha}^{-1}$ ) was characterized by the lowest amount of the identified pathogens. Commercial SP applied at $80 \mathrm{~kg}$ $\mathrm{P}_{2} \mathrm{O}_{5} \mathrm{ha}^{-1}$ (clade 3 ) induced the most pronounced changes in the fungal taxa colonizing wheat grain relative to non-fertilized plants. The above was attributed mainly to the lower amount of $A$. infectoria and higher counts of species of the family Nectriaceae, mostly epiphytic pathogens Fusarium culmorum and Fusarium poae.
\end{abstract}

Keywords: Alternaria; Fusarium; Illumina MiSeq; secondary raw materials

\section{Introduction}

Spring wheat (Triticum aestivum L.) is infected by several dozens of pathogenic fungi. Species such as Mycosphaerella graminicola, Pyrenophora tritici-repentis, Tilletia caries, and Ustilago tritici, as well as numerous species of the genus Fusarium are the most dangerous pathogens of wheat that are transmitted with grain [1]. Fungal species of the genera Alternaria, Cladosporium, and Epiccocum are regarded as weak pathogens or saprotrophs [2]. Research has demonstrated close interactions between plants and microbes [2]. Wheat grain is infected by fungal pathogens, but it is also colonized by non-pathogenic fungi which inhibit the proliferation of pathogens and promote the growth and development of wheat plants $[3,4]$. The interactions between these fungal groups determine grain health and improve the consumer value of grain by reducing its mycotoxin content $[3,5,6]$. Growing conditions and nutrient availability can exert both positive and negative effects on the occurrence of pathogenic and non-pathogenic fungi [5-7].

Phosphorus is essential for root growth, healthy development of stems and ears, a desirable growth rate, high yield and quality, and resistance to abiotic and biotic stress factors [8]. Among the latter, fungal pathogens deserve special attention. A high supply of plant-available phosphorus has been linked with increased levels of fungistatic components, such as phenolic compounds and 
flavonoids, in different plant parts [9]. The indirect effect of phosphorus on increased plant growth seems to outweigh the direct effect of fungi by increasing the synthesis of phenolic compounds which contribute to resistance against fungal pathogens [10]. Since the natural amount of available phosphorus in arable soils does not fully cater to the nutritional needs of plants [11], crops have to be fertilized [12]. Phosphate rock is the raw material for the production of phosphorus fertilizers [13] which are indispensable in modern agriculture [14].

Rational phosphorus management poses a contemporary global challenge [15-17]. Primary sources of phosphorus are being massively wasted in the production process and it is estimated that only $20-25 \%$ of mined phosphorus reaches the produced food [17]. The above raises significant concerns about the availability of phosphorus for agriculture in the future [16]. Global phosphorus resources have not yet reached critical levels [18], but they are undeniably limited and non-renewable. Phosphate rock is distributed unevenly around the world [18] and many countries are dependent on phosphorus imports [19]. This problem applies to the European Union, which has recently added phosphate rock to the list of 20 critical raw materials [20].

Recycled phosphorus provides an alternative to non-renewable phosphate rock deposits [14]. The most abundant secondary sources of phosphorus include sewage and sludge from municipal and industrial wastewater treatment plants [21,22] and waste products from the meat processing industry [23].

Unprocessed phosphorus compounds from both primary and secondary sources are characterized by low solubility [24]. Fertilizer efficiency can be improved through the use of phosphorus solubilizing microbes (PSMs) which transform insoluble phosphorus compounds $\left(\mathrm{PO}_{4}{ }^{3-}\right)$ into highly bioavailable forms $\left(\mathrm{HPO}_{4}{ }^{2-}\right.$ and $\left.\mathrm{H}_{2} \mathrm{PO}_{4}{ }^{-}\right)[4,25,26]$. PSMs are a natural component of the soil edaphon [11]. Bacillus megaterium is one of the most effective PSMs [27]. These bacteria solubilize phosphorus by producing weak organic acids (gluconic, lactic, acetic, and succinic) [28]. Through solubilization and other biological mechanisms, PSMs can also act as plant growth-promoting microorganisms (PGPMs) [25,29]. It could be expected that by solubilizing phosphorus from soil and fertilizers, PSMs could contribute to a reduction in the fertilizer rate. The production of phosphorus biofertilizers from cheap renewables resources by PSMs promotes sustainable phosphorus management [16] and contributes to a circular economy [30].

Research into the production of phosphorus biofertilizers has been conducted by a Polish scientific consortium established by the Wrocław University of Science and Technology, the New Chemical Syntheses Institute in Puławy, and the University of Warmia and Mazury in Olsztyn [31]. Innovative biofertilizers are expected to deliver similar yield-forming effects to chemical fertilizers and to guarantee the safety of the produced crops. One of the most recent research concepts postulates the use of sewage sludge ash, dried animal blood, and B. megaterium in the production of biofertilizers.

This research aimed to determine the effect of the fertilizers produced from sewage sludge ash and dried animal blood on the species composition and structure of fungal communities colonizing wheat grain. The recycled fertilizer (Rec) and biofertilizer (Bio), i.e., Rec activated by B. megaterium, were assessed against commercial superphosphate. Mycological analyses were conducted using culture-dependent methods based on fungal sporulation as well as next-generation sequencing in the Illumina MiSeq system.

\section{Materials and Methods}

\subsection{Field Experiment}

A field experiment was carried out in 2016 in Bałcyny (Poland, $53^{\circ} 60^{\prime} \mathrm{N}, 19^{\circ} 85^{\prime} \mathrm{E}$ ). The experimental plant was spring wheat (Triticum aestivum ssp. vulgare) cv. Monsun sown on 21 April at 450 plants $\mathrm{m}^{-2}$, at a depth of 3-4 cm, at a row spacing of $15 \mathrm{~cm}$.

The experimental factor was phosphorus fertilization (Table 1). Granular recycled phosphorus fertilizer (Rec) and biofertilizer (Bio) were compared with commercial superphosphate (SP; Gdańskie 
Zakłady Nawozów Fosforowych Fosfory Sp. z o.o., Gdańsk, Poland). Phosphorus fertilizers were applied before sowing at 40, 60, and $80 \mathrm{~kg} \mathrm{P}_{2} \mathrm{O}_{5}$ per ha. The fertilizers from recyclables (Rec and Bio) were produced by the New Chemical Syntheses Institute in Puławy based on the formula developed by the Department of Advanced Material Technologies of the Wrocław University of Science and Technology. Sewage sludge ash was obtained from the Łyna Municipal Wastewater Treatment Plant in Olsztyn, and dried animal blood was obtained from the meat industry. The bacterial strain of B. megaterium was obtained from the Polish Collection of Microorganisms of the Institute of Immunology and Experimental Therapy of the Polish Academy of Sciences in Wrocław (Poland). The procedure of obtaining fertilizer formulations was described by Rolewicz et al. [32].

Table 1. Elemental composition of phosphorus fertilizers.

\begin{tabular}{|c|c|c|c|}
\hline P-Fertilizer & $\begin{array}{l}\mathrm{P}_{2} \mathrm{O}_{5} \text { Rate, } \\
\mathrm{kg} \mathrm{ha}^{-1}\end{array}$ & $\begin{array}{c}\text { Treatment } \\
\text { Symbol }\end{array}$ & $\begin{array}{c}\text { Fertilizer Characteristics } \\
\text { (Elemental Composition of Fertilizers) }\end{array}$ \\
\hline Control & 0 & $\mathrm{CO}$ & No P fertilization \\
\hline Superphosphate & $\begin{array}{l}40 \\
60 \\
80\end{array}$ & $\begin{array}{l}\text { SP40 } \\
\text { SP60 } \\
\text { SP80 }\end{array}$ & $\begin{array}{l}\text { Fosdar }{ }^{\mathrm{TM}} 40 \text { commercial superphosphate fertilizer } \\
\left(\mathrm{P}_{2} \mathrm{O}_{5} 40 \% ; \mathrm{CaO} 10 \% ; \mathrm{SO}_{3} 5 \% \text {; trace presence: } \mathrm{Fe}, \mathrm{Zn} \text {, }\right. \\
\mathrm{Cu}, \mathrm{B}, \mathrm{Co}, \mathrm{Mn}, \mathrm{Mo})^{1}\end{array}$ \\
\hline Recycled fertilizer & 80 & Rec60 & 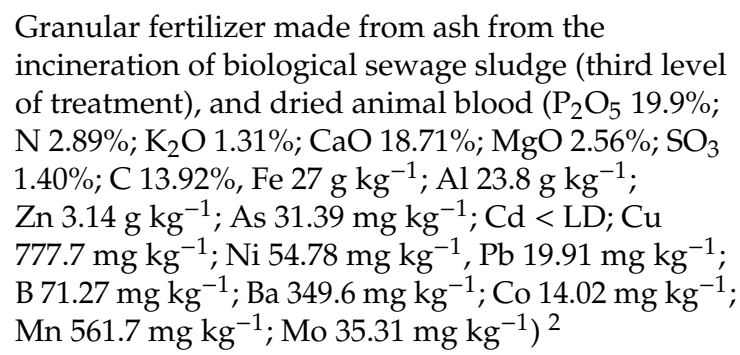 \\
\hline Recycled biofertilizer & 40 & Bio40 & 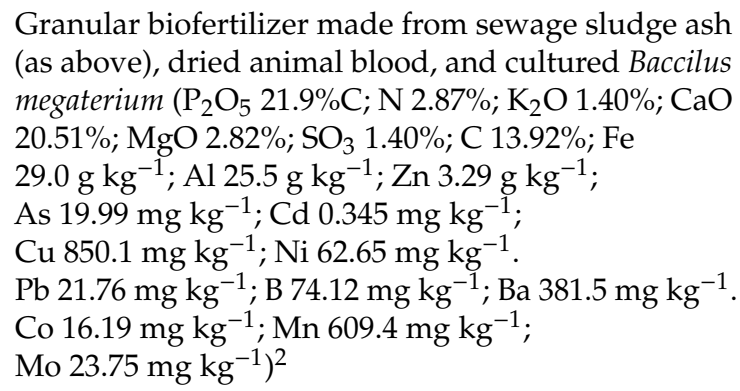 \\
\hline
\end{tabular}

${ }^{1}$ according to the information provided on the label, ${ }^{2}$ according to the Department of Advanced Material Technologies of the Wrocław University of Science and Technology, LD-level of detection.

The field experiment had a randomized block design with four replications. The experimental plots had an area of $20 \mathrm{~m}^{2}$ each. Winter oilseed rape was the preceding crop. In addition to phosphorus fertilization, wheat in all plots was fertilized with nitrogen at $130 \mathrm{~kg} \mathrm{~N} \mathrm{ha}^{-1}(34 \%$ ammonium nitrate, Grupa Azoty Puławy, Poland) and potassium at $100 \mathrm{~kg} \mathrm{~K}_{2} \mathrm{O} \mathrm{ha}^{-1}(60 \%$ potash salt, Luvena, Luboń, Poland). Potassium was applied at a single rate before sowing, and nitrogen was split into three applications: $60 \mathrm{~kg}$ before sowing, $50 \mathrm{~kg}$ in the stem elongation stage (BBCH 30) [33], and $20 \mathrm{~kg}$ in the heading stage (BBCH 55).

Wheat was protected against diseases, weeds, and pests (Table 2) and was harvested with a plot harvester on August 12. 
Table 2. Plant protection treatments applied in the field experiment.

\begin{tabular}{|c|c|c|c|c|}
\hline Pesticide Type & $\begin{array}{c}\text { Trade Name } \\
\text { (Manufacturer) }\end{array}$ & Active Ingredient $\left(\mathrm{g} \mathrm{dm}^{-3}\right)$ & Rate $\left(\mathrm{dm}^{3} \mathrm{ha}^{-3}\right)$ & Application Time \\
\hline Herbicides & $\begin{array}{c}\text { Mustang } 309 \mathrm{SE} \\
\left(\text { Dow AgroSciences }{ }^{1} \text { ) }\right.\end{array}$ & $\begin{array}{c}\text { Florasulam (6.25) + 2,4-D } \\
\qquad(300)\end{array}$ & 0.5 & $\begin{array}{c}\text { Flag leaf stage } \\
\text { (BBCH 39; } 29 \text { May) }\end{array}$ \\
\hline \multirow[t]{2}{*}{ Fungicides } & $\begin{array}{l}\text { Yamato } 303 \text { SE } \\
\left(\text { Sumi Agro }^{1}\right)\end{array}$ & $\begin{array}{c}\text { Thiophanate-methyl (233) + } \\
\text { Tetraconazole (70) }\end{array}$ & 1.5 & $\begin{array}{l}\text { Early boot stage } \\
\text { (BBCH 41; } 9 \text { June) }\end{array}$ \\
\hline & $\begin{array}{c}\text { Amistar } 250 \text { SC } \\
\left(\text { Syngenta }{ }^{1}\right)\end{array}$ & Azoxystrobin (250) & 0.8 & $\begin{array}{l}\text { End of flowering } \\
\text { (BBCH 69; } 8 \text { July) }\end{array}$ \\
\hline Insecticides & $\begin{array}{c}\text { Karate Zeon } 050 \text { CS } \\
\left(\text { Syngenta }{ }^{1}\right)\end{array}$ & Lambda-cyhalothrin (50) & 0.1 & $\begin{array}{l}\text { Early boot stage } \\
\text { (BBCH 41; } 6 \text { June) }\end{array}$ \\
\hline
\end{tabular}

${ }^{1}$ Warsaw, Poland.

\subsection{Soil and Meteorological Conditions}

Wheat was grown on luvisol [34] formed from sandy clay loam. The arable layer was slightly acidic (average $\mathrm{pH}$ of 6.28 in $1 \mathrm{M} \mathrm{KCl}$ ). At the beginning of the experiment in 2016, soil contained $8.53 \mathrm{~g} \mathrm{~kg}^{-1} \mathrm{C}, 1.42 \mathrm{~g} \mathrm{~kg}^{-1} \mathrm{~N}, 2975 \mathrm{mg} \mathrm{kg}^{-1} \mathrm{~K}$, and $607 \mathrm{mg} \mathrm{kg}^{-1} \mathrm{P}$ (total content). Soil phosphorus content after spring wheat harvest is presented in Table 3.

Table 3. Total P content of soil after spring wheat harvest (mean \pm standard error).

\begin{tabular}{cc}
\hline P-Treatment & Total $\mathbf{P}, \mathbf{~ m g ~ k g}^{-\mathbf{1}}$ \\
\hline C0 & $540.3 \pm 5.9$ \\
\hline SP40 & $590.7 \pm 18.1$ \\
SP60 & $603.1 \pm 9.7$ \\
SP80 & $612.9 \pm 23.9$ \\
\hline Rec40 & $604.3 \pm 4.7$ \\
Rec60 & $613.2 \pm 11.9$ \\
Rec80 & $626.3 \pm 36.6$ \\
\hline Bio40 & $597.4 \pm 17.7$ \\
Bio60 & $611.2 \pm 16.4$ \\
Bio80 & $621.5 \pm 13.7$ \\
\hline
\end{tabular}

Abbreviations are explained in Table 1.

Mean annual precipitation was $62.5 \mathrm{~mm}$, with $66.3 \mathrm{~mm}$ in June, $138.6 \mathrm{~mm}$ in July, $71.9 \mathrm{~mm}$ in August, and $17.1 \mathrm{~mm}$ in September. Mean annual temperature was $8.8^{\circ} \mathrm{C}$, and the mean monthly temperature ranged from $-3.8^{\circ} \mathrm{C}$ in January to $18.5^{\circ} \mathrm{C}$ in July.

\subsection{Isolation of Fungi from Grain}

Grain was harvested in the over-ripe stage (BBCH 92) with a plot harvester on 12 August 2016. Fungal colonization of grain was analyzed, and fungal DNA was isolated immediately after harvest. Grain samples of $10 \mathrm{~g}$ each were placed in $250 \mathrm{~cm}^{3}$ flasks containing $90 \mathrm{~cm}^{3}$ of sterile water and $0.01 \mathrm{~cm}^{3}$ of Tween $® 40$ (Merck, Darmstadt, Germany). The flasks were shaken for $60 \mathrm{~min}$ on an Elpin Plus 358 S table shaker (180 rpm, Elpin Plus, Lubawa, Poland) to remove microorganisms from grain. Using a pipette, $0.1 \mathrm{~cm}^{3}$ of the propagule suspension was transferred to Petri plates with a diameter of $9 \mathrm{~cm}$ and flooded with selective Martin medium [35] cooled to $42{ }^{\circ} \mathrm{C}$. The experiment was conducted in four replications. Yeasts and filamentous fungi cultured on the Martin medium were incubated at $24{ }^{\circ} \mathrm{C}$ in darkness for 7 days (En 120 Incubator, Nuve, Ancara, Turkey). Yeast and fungal colonies were counted on plates, and different colonies of filamentous fungi were transferred to Petri plates filled with potato dextrose agar (PDA, Merck, Warsaw, Poland) for species identification under a microscope. The number of colony forming units (CFUs) was log-transformed (CFU+1). One hundred disinfected and non-disinfected kernels from each treatment were placed on PDA. Kernels were disinfected by 
immersion in $1 \%$ sodium hypochlorite ( $\mathrm{NaOCl}, \mathrm{ABO}$, Gdańsk, Poland) solution for 5 min and they were then rinsed three times in sterile water and dried on blotting paper. Colonies of filamentous fungi were identified at the species level based on the sporulation characteristics described in the literature [36,37].

\subsection{Isolation of Fungal DNA and PCR Amplification}

Fungal DNA was isolated directly from grain with the Bead-Beat Micro AX Gravity Kit (A\&A Biotechnology, Gdynia, Poland) according to the manufacturer's protocol. The quantity and quality of the isolated DNA were tested by measuring absorbance at 260 and $280 \mathrm{~nm}$ (NanoDrop 2000, Thermo Scientific, Wilmington, DE, USA). A metagenomic analysis of the fungal community was carried out in the ITS2 hypervariable region. The selected region was amplified and the library was prepared with the use of three specific primer sequences: fITS7 (GTGARTCATCGAATCTTTG), ITS4 (TCCTCCGCTTATTGATATGC) and an additional adapter sequence at the $5^{\prime}$ end. PCR was conducted with the Q5 Hot Start High-Fidelity 2X Master Mix under the conditions recommended by the manufacturer. The Nextera Index Kit was used to add specific index adapter sequences to both ends of the analyzed DNA fragment.

\subsection{Illumina MiSeq Sequencing}

The samples were sequenced in the Illumina MiSeq system (Poland) in paired-end (PE) mode, $2 \times 250 \mathrm{nt}$, with the Illumina v2 kit (Genomed S.A., Warsaw, Poland). A preliminary analysis of the results was performed automatically in the MiSeq system with MiSeq Reporter (MSR) v2.6 software (Illumina, USA). The analysis was conducted in two steps: (1) automatic demultiplexing of samples, and (2) generation of fastq files with raw read data. A bioinformatics analysis with operational taxonomic unit (OTU) picking was conducted in the QIIME (Quantitative Insights Into Microbial Ecology) program based on the reference sequences in UNITE $\mathrm{v} 7$ [38]. The bioinformatics analysis was conducted in the following steps: (1) analysis of read quality and removal of low-quality sequences (quality $<20$, minimal length-30)—cutadapt, (2) joining pair-ended sequences—fastq-join, (3) clustering based on a selected database of reference sequences-uclust, (4) removal of chimeric sequences with the usearch61 algorithm [39], and (5) taxonomic identification based on the UNITE-BLAST [40].

\subsection{Statistical Analysis}

The analysis of variance (ANOVA) was performed in the Statistica 13 program [41]. The significance of differences between mean values was determined by the Newman-Keuls test or Tukey's test $(p<0.01)$. The taxonomic status of fungi obtained by sequencing in the Illumina MiSeq system was presented in heat maps for each product [42]. Hierarchical cluster analysis was carried out on ln-transformed DNA data for OTU 1-10. The Ward clustering method [43] was used based on a dissimilarity matrix representing Euclidean distances between OTUs relative to their prevalence in seed samples of different origin. To examine the correlations between OTUs more closely, the DNA data for OTU 1-10 were subjected to principal component analysis (PCA), and the results were visualized in a biplot.

\section{Results}

\subsection{Fungal Colony Counts on Wheat Grain}

Five pathogenic species of the genus Fusarium (F. culmorum, F. poae, F. graminearum, F. avenaceum and F. solani), species of the genus Alternaria (Alternaria sect. alternata and Alternaria sect. infectoriae) and, sporadically, Pyrenophora- tritici-repentis and Rhizoctonia cerealis were isolated from wheat grain (Table 4). The CFUs of epiphytic Alternaria spp. were significantly higher in nearly all grain samples (excluding grain from treatments fertilized with SP60, Rec60, and Rec80) relative to control grain (C0) where the above pathogen was not detected. The colony counts of Alternaria spp. were highest in wheat kernels from treatments supplied with the biofertilizer (Bio40). Fusarium culmorum and 
F. graminearum were detected in eight out of the 10 analyzed grain samples. Fusarium culmorum was the predominant species in treatments with the highest rate of the commercial fertilizer. The colony counts of $F$. graminearum were significantly higher in treatments supplied with the biofertilizer (Bio40, 60, and 80), Rec80, and SP60 than in the control treatment. The pathogenic species P. tritici-repentis and R. cerealis were identified only in the Bio80 treatment.

Table 4. Pathogens contaminating wheat grain.

\begin{tabular}{cccccccc}
\hline \multirow{2}{*}{ P-Treatment } & $\begin{array}{c}\text { Alternaria } \\
\text { spp. }\end{array}$ & $\begin{array}{c}\text { Fusarium } \\
\text { culmorum }\end{array}$ & $\begin{array}{c}\text { Fusarium } \\
\text { poae }\end{array}$ & $\begin{array}{c}\text { Fusarium } \\
\text { graminearum }\end{array}$ & $\begin{array}{c}\text { Fusarium } \\
\text { avenaceum }\end{array}$ & $\begin{array}{c}\text { Fusarium solani } \\
\text { Species Complex }\end{array}$ & Other $^{1}$ \\
\cline { 2 - 7 } & \multicolumn{7}{c}{ Log (CFU + 1) per 1 g of grain } \\
\hline C0 & $0^{\mathrm{d}}$ & $0^{\mathrm{c}}$ & $1.28^{\mathrm{a}}$ & $0.35^{\mathrm{bc}}$ & $0^{\mathrm{c}}$ & 0 & $0^{\mathrm{b}}$ \\
SP40 & $1.23^{\mathrm{abc}}$ & $0.84^{\mathrm{abc}}$ & $0^{\mathrm{b}}$ & $0.94^{\mathrm{ab}}$ & $0.35^{\mathrm{bc}}$ & 0 & $0^{\mathrm{b}}$ \\
SP60 & $0.44^{\mathrm{cd}}$ & $0^{\mathrm{c}}$ & $1.42^{\mathrm{a}}$ & $1.19^{\mathrm{a}}$ & $0^{\mathrm{c}}$ & 0 & $0^{\mathrm{b}}$ \\
$\mathrm{SP} 80$ & $1.38^{\mathrm{abc}}$ & $1.57^{\mathrm{a}}$ & $0^{\mathrm{b}}$ & $0.35^{\mathrm{bc}}$ & $0^{\mathrm{c}}$ & 0 & $0^{\mathrm{b}}$ \\
$\operatorname{Rec} 40$ & $1.23^{\mathrm{abc}}$ & $1.04^{\mathrm{ab}}$ & $0^{\mathrm{b}}$ & $0^{\mathrm{c}}$ & $0^{\mathrm{c}}$ & 0 & $0^{\mathrm{b}}$ \\
Rec60 & $0.35^{\mathrm{d}}$ & $0.69^{\mathrm{abc}}$ & $0^{\mathrm{b}}$ & $0^{\mathrm{c}}$ & $0^{\mathrm{c}}$ & 0 & $0^{\mathrm{b}}$ \\
Rec80 & $0.44^{\mathrm{cd}}$ & $0.35^{\mathrm{bc}}$ & $0^{\mathrm{b}}$ & $1.43^{\mathrm{a}}$ & $0^{\mathrm{c}}$ & 0.44 & $0^{\mathrm{b}}$ \\
Bio40 & $1.64^{\mathrm{a}}$ & $0.88^{\mathrm{abc}}$ & $0^{\mathrm{b}}$ & $1.49^{\mathrm{a}}$ & $0.69^{\mathrm{ab}}$ & 0 & $0^{\mathrm{b}}$ \\
Bio60 & $1.03^{\mathrm{abc}}$ & $1.19^{\mathrm{ab}}$ & $0^{\mathrm{b}}$ & $1.33^{\mathrm{a}}$ & $0^{\mathrm{c}}$ & 0 & $0^{\mathrm{b}}$ \\
Bio80 & $1.48^{\mathrm{a}}$ & $0.35^{\mathrm{bc}}$ & $0^{\mathrm{b}}$ & $1.40^{\mathrm{a}}$ & $1.04^{\mathrm{a}}$ & 0 & $1.14^{\mathrm{a}}$ \\
\hline
\end{tabular}

${ }^{1}$ Pyrenophora tritici-repentis, Rhizoctonia cerealis. Values in columns that did not differ significantly in the Newman-Keuls test $(p<0.01)$ are marked with identical letters; values not marked with letters do not differ significantly (abbreviations are explained in Table 1).

The most prevalent non-pathogenic fungi were yeasts (2.34-2.87 Log(CFU + 1)) and Mycosphaerella tassiana $(2.05-2.71 \mathrm{Log}(\mathrm{CFU}+1))$ (Table 5). Yeast counts were significantly higher on grain harvested from treatments fertilized with Bio40 and Bio80 in comparison with the SP80 treatment. Species of the genus Acremonium were also relatively abundant in all analyzed grain samples. The colony counts of Penicillium spp. were significantly higher in treatment SP80 than in the control treatment (C0). The method of isolation from non-disinfected grains allowed to detect huge yeast communities and six species of pathogenic fungi.

Table 5. Non-pathogenic fungi colonizing wheat grain.

\begin{tabular}{|c|c|c|c|c|c|c|}
\hline \multirow[t]{2}{*}{ P-Treatment } & Yeasts & $\begin{array}{c}\text { Mycosphaerella } \\
\text { tassiana }\end{array}$ & $\begin{array}{l}\text { Acremonium } \\
\text { spp. }\end{array}$ & Mucor spp. & $\begin{array}{c}\text { Aspergillus } \\
\text { spp. }\end{array}$ & $\begin{array}{l}\text { Penicillium } \\
\text { spp. }\end{array}$ \\
\hline & \multicolumn{6}{|c|}{$\log (C F U+1)$ per $1 \mathrm{~g}$ of grain } \\
\hline $\mathrm{C} 0$ & $2.58^{\mathrm{ab}}$ & $2.41^{\mathrm{abc}}$ & $1.55^{\mathrm{abc}}$ & 0 & $0.44^{\mathrm{ab}}$ & $0^{\mathrm{b}}$ \\
\hline SP40 & $2.55^{\mathrm{ab}}$ & $2.56^{\mathrm{abc}}$ & $1.76^{\mathrm{abc}}$ & 0.34 & $1.04^{\mathrm{a}}$ & $0^{b}$ \\
\hline SP60 & $2.64^{\mathrm{ab}}$ & $2.33^{c}$ & $1.84^{\mathrm{abc}}$ & 0 & $0.35^{\mathrm{b}}$ & $0^{\mathrm{b}}$ \\
\hline SP80 & $2.34^{b}$ & $2.05^{\mathrm{c}}$ & $0.94^{\mathrm{c}}$ & 0 & $0^{b}$ & $2.21^{\mathrm{a}}$ \\
\hline $\operatorname{Rec} 40$ & $2.75^{\mathrm{ab}}$ & $2.20^{\mathrm{c}}$ & $1.97^{\mathrm{ab}}$ & 0 & $0^{b}$ & $0^{\mathrm{b}}$ \\
\hline Rec60 & $2.62^{a b}$ & $2.71^{\mathrm{a}}$ & $1.38^{a b c}$ & 0 & $0^{\mathrm{b}}$ & $0^{\mathrm{b}}$ \\
\hline $\operatorname{Rec} 80$ & $2.79 \mathrm{ab}$ & $2.35^{c}$ & $2.33^{\mathrm{a}}$ & 0 & $0^{b}$ & $0^{b}$ \\
\hline Bio40 & $2.84^{\mathrm{a}}$ & $2.56^{\mathrm{abc}}$ & $1.18^{\mathrm{bc}}$ & 0 & $0^{\mathrm{b}}$ & $0^{b}$ \\
\hline Bio60 & $2.79 \mathrm{ab}$ & $2.64^{\mathrm{ab}}$ & $2.34^{\mathrm{a}}$ & 0 & $0^{\mathrm{b}}$ & $0^{b}$ \\
\hline Bio80 & $2.87^{\mathrm{a}}$ & $2.54^{a b c}$ & $1.92^{a b}$ & 0 & $0.35^{b}$ & $0^{b}$ \\
\hline
\end{tabular}

Values in columns that did not differ significantly in the Newman-Keuls test $(p<0.01)$ are marked with identical letters; values not marked with letters do not differ significantly (abbreviations are explained in Table 1).

\subsection{Percentage of Pathogenic and Saprotrophic Fungi Colonizing Grain on PDA}

Dark fungal colonies of the genus Alternaria were prevalent on non-disinfected kernels cultured on PDA, and they were identified in $14.81 \%$ of grain samples from treatments SP80 and Rec40 to $27.78 \%$ of grain samples from treatment Rec80 (Table 6). Fusarium fungi were encountered most frequently on kernels from plots fertilized with superphosphate (SP) and control plots (C0). Four Fusarium 
species-F. avenaceum, F. graminearum, F. poae, and F. sporotrichioides-were identified on $14.82 \%$ of control kernels. Three Fusarium species were also abundant on grain samples from treatments supplied with the commercial phosphorus fertilizer (14.82\% in treatment SP40, 12.96\% in treatments SP60 and SP80). The second method of isolation from disinfected grain appeared to yield more Fusarias.

Table 6. Percentage of non-disinfected wheat grain colonized by epiphytic fungi.

\begin{tabular}{cccccccc}
\hline P-Treatment & $\begin{array}{c}\text { Alternaria } \\
\text { spp. }\end{array}$ & $\begin{array}{c}\text { Fusarium } \\
\text { avenaceum }\end{array}$ & $\begin{array}{c}\text { Fusarium } \\
\text { graminearum }\end{array}$ & $\begin{array}{c}\text { Fusarium } \\
\text { poae }\end{array}$ & $\begin{array}{c}\text { Fusarium } \\
\text { sporotrichioides }\end{array}$ & $\begin{array}{c}\text { Epicoccum } \\
\text { nigrum }\end{array}$ & $\begin{array}{c}\text { Botrytis } \\
\text { cinerea }\end{array}$ \\
\hline C0 & 20.37 & 5.56 & 1.85 & 5.56 & 1.85 & 1.85 & 0 \\
SP40 & 16.67 & 5.56 & 0 & 1.85 & 7.41 & 0 & 1.85 \\
SP60 & 24.07 & 1.85 & 0 & 3.70 & 7.41 & 0 & 0 \\
SP80 & 14.81 & 3.70 & 3.70 & 5.56 & 0 & 1.85 & 1.85 \\
Rec40 & 14.81 & 1.85 & 0 & 5.57 & 1.85 & 3.70 & 0 \\
Rec60 & 25.93 & 3.70 & 0 & 0 & 3.70 & 0 & 0 \\
Rec80 & 27.78 & 0 & 1.85 & 3.70 & 1.85 & 0 & 0 \\
Bio40 & 25.93 & 0 & 0 & 1.85 & 3.70 & 0 & 0 \\
Bio60 & 22.22 & 0 & 0 & 1.85 & 0 & 5.56 & 0 \\
Bio80 & 20.37 & 0 & 0 & 3.70 & 0 & 0 & 0 \\
\hline
\end{tabular}

No significant differences between treatments (abbreviations are explained in Table 1).

The percentage of disinfected kernels contaminated with fungi of the genus Alternaria ranged from $18.52 \%$ (SP60, Bio40) to 31.48\% (Rec40) (Table 7). Fusarium fungi colonized less than $4 \%$ of disinfected kernels. The only exception was disinfected grain from treatment Bio40 which was colonized by F. sporotrichioides at $5.56 \%$.

Table 7. Percentage of disinfected wheat kernels colonized by endophytic fungi.

\begin{tabular}{|c|c|c|c|c|c|c|c|c|c|}
\hline P-Treatment & $\begin{array}{l}\text { Alternaria } \\
\text { spp. }\end{array}$ & $\begin{array}{l}\text { Fusarium } \\
\text { avenaceum }\end{array}$ & $\begin{array}{c}\text { Fusarium } \\
\text { graminearum }\end{array}$ & $\begin{array}{l}\text { Fusarium } \\
\text { oxysporum }\end{array}$ & $\begin{array}{l}\text { Fusarium } \\
\text { poae }\end{array}$ & $\begin{array}{l}\text { Fusarium solani } \\
\text { Species Complex }\end{array}$ & $\begin{array}{c}\text { Fusarium } \\
\text { sporotrichioides }\end{array}$ & $\begin{array}{l}\text { Epicoccum } \\
\text { nigrum }\end{array}$ & $\begin{array}{l}\text { Botrytis } \\
\text { cinerea }\end{array}$ \\
\hline $\mathrm{C} 0$ & 27.78 & 0 & 3.70 & 0 & 1.85 & 0 & $0^{\mathrm{b}}$ & 1.85 & 0 \\
\hline SP40 & 24.07 & 1.85 & 1.85 & 0 & 0 & 0 & $1.85^{\mathrm{ab}}$ & 1.85 & 1.85 \\
\hline SP60 & 18.52 & 0 & 0 & 1.85 & 0 & 1.85 & $0^{\mathrm{b}}$ & 0 & 1.85 \\
\hline SP80 & 22.22 & 3.70 & 0 & 1.85 & 0 & 0 & $0^{\mathrm{b}}$ & 0 & 0 \\
\hline $\operatorname{Rec} 40$ & 31.48 & 3.70 & 0 & 0 & 0 & 1.85 & $0^{\mathrm{b}}$ & 0 & 0 \\
\hline Rec60 & 29.63 & 0 & 0 & 0 & 3.70 & 0 & $0^{\mathrm{b}}$ & 0 & 0 \\
\hline $\operatorname{Rec} 80$ & 29.63 & 1.85 & 0 & 0 & 0 & 0 & $1.85^{\mathrm{ab}}$ & 0 & 0 \\
\hline Bio40 & 18.52 & 0 & 0 & 0 & 0 & 0 & $5.56^{\mathrm{a}}$ & 1.85 & 0 \\
\hline Bio60 & 25.93 & 0 & 0 & 0 & 1.85 & 0 & $0^{\mathrm{b}}$ & 0 & 0 \\
\hline Bio80 & 24.07 & 1.85 & 1.85 & 0 & 1.85 & 0 & $1.85^{\mathrm{ab}}$ & 0 & 0 \\
\hline
\end{tabular}

Values in columns that did not differ significantly in Tukey's test $(p<0.01)$ are marked with identical letters; values not marked with letters do not differ significantly (abbreviations are explained in Table 1).

\subsection{Structure and Composition of Fungal Communities}

The biodiversity of fungal communities was analyzed by next-generation sequencing in the Illumina MiSeq system. The sequence of the ITS region was compared with the sequences from the UNITE-BLAST database to reveal that fungi of the phylum Ascomycota predominated in all grain samples and accounted for $91.99 \%$ (Bio40) to $98.92 \%$ of OTUs (Rec40). Fungi of the phylum Basidiomycota accounted for $0.38 \%$ (Rec60) to 1.7\% (SP60) of sequence reads. Species of the genus Alternaria, family Pleosporaceae, order Pleosporares, class Dothideomycetes accounted for $58.06 \%$ (SP80) to $95.35 \%$ (Rec60) of reading frames in the ITS2 region. A very high percentage of Alternaria fungi were classified as $A$. infectoria $(43.41-92.79 \%)$, whereas only $2.43-16.3 \%$ were identified as A. betae-kenyensis (Figure 1).

Fungi of the genus Gibberella, family Nectriaceae, order Hypocreales were identified in all grain samples (Table 8, Figure 1). They were represented mainly by the pathogenic species Gibberella tricincta which was most abundant in grain samples from treatments SP80 (4.5\% OTUs), Bio60 (4.5\%), and Bio80 $(5.48 \%)$. Grain samples from treatments C0, SP60, and Bio40 were also colonized by unidentified Gibberella species. Unidentified pathogenic species of the genus Fusarium (family Nectriaceae) were 
identified in grain samples from treatments SP40 and Bio40. The pathogenic species Monographella nivalis of the order Xylariales, class Sordariomycetes was detected in seven grain samples, excluding samples from treatments SP40, Rec40, Rec60. Monographella nivalis accounted for 11\% reading frames in control grain (C0). The pathogenic species P. tritici-repentis of the family Pleosporaceae, order Pleosporales, class Dothideomycetes was detected in grain from treatments Rec40 (1.73\% OTUs), Rec80 (3.33\% OTUs), Bio40 (2.41\% OTUs), Bio60 (5.89\% OTUs), and Bio80 (2.46\% OTUs). A metagenomic analysis also demonstrated the presence of biotrophic species of the genus Ustilago, family Ustilaginaceae, order Ustilaginales, class Ustilaginomycetes, phylum Basidiomycota (Table 8, Figure 1). These fungi were identified only on grain from treatment Rec 80 ( $0.41 \%$ OTUs). Fungi of the genus Ustilago cannot be isolated on synthetic media in a laboratory. The saprotrophic species $M$. tassiana of the family Mycosphaerellaceae, order Capnodiales, class Dothideomycetes colonized seven out of the 10 analyzed grain samples, and it accounted for $0.6 \%$ (Rec60) to $8 \%$ (Bio80) of reading frames. Unidentified species of the genus Mycosphaerella represented 1.6\% (SP80), 0.6\% (Bio40), and 1\% (Bio60) of reading frames.

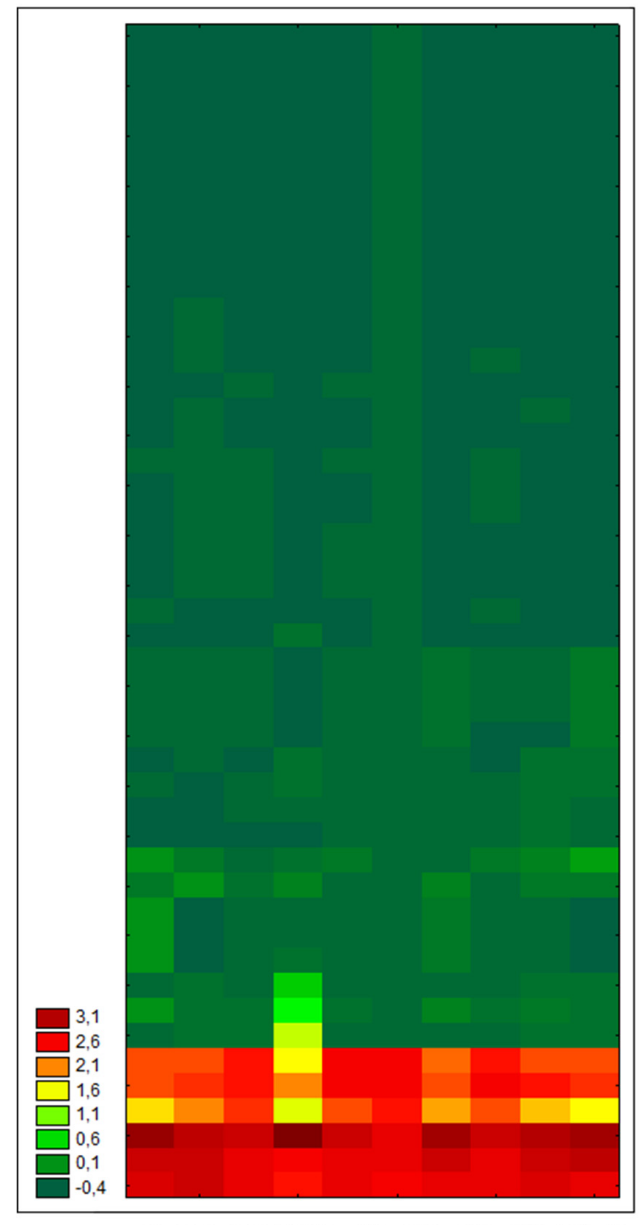

C0 SP40 SP60 SP80Rec40 Rec60Rec80 Bio40Bio60 Bio80

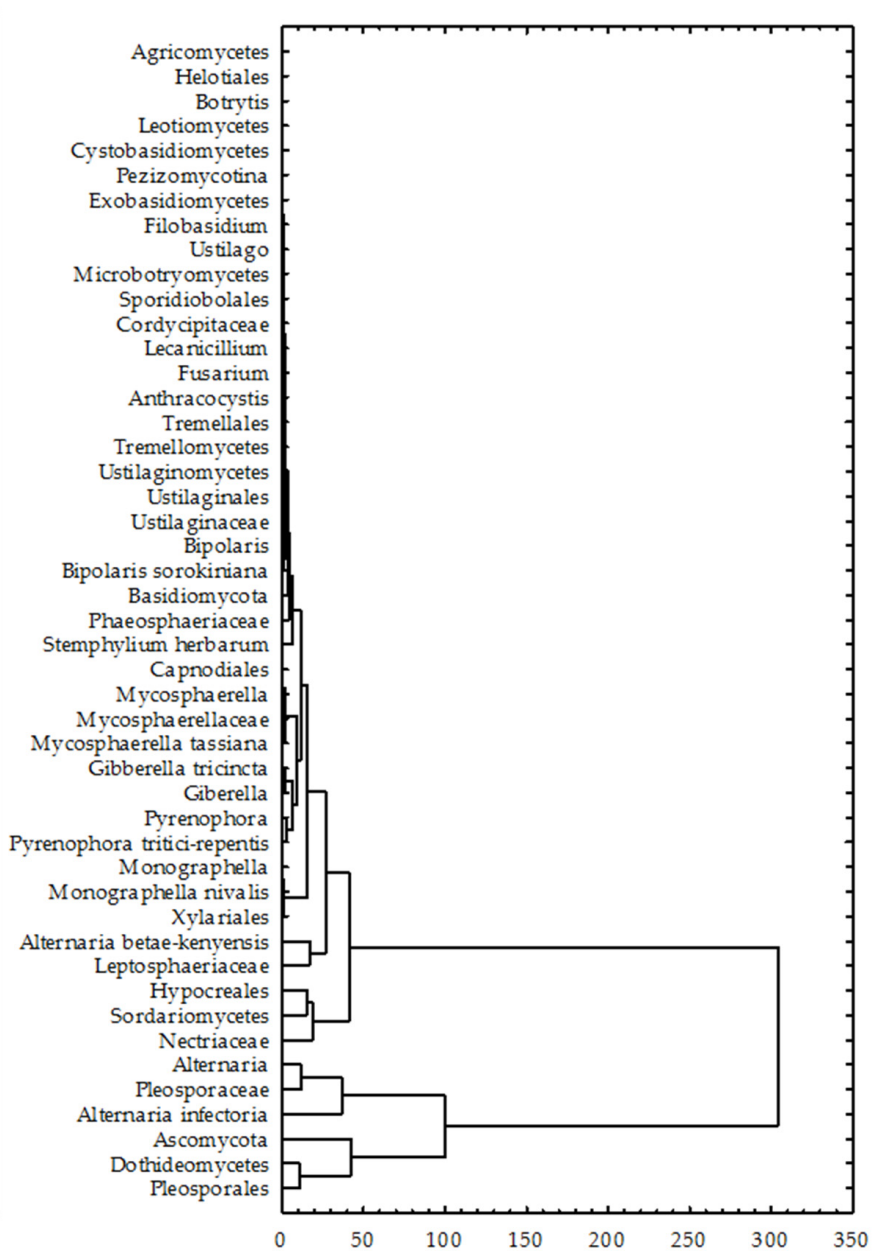

(a)

Figure 1. Cont. 


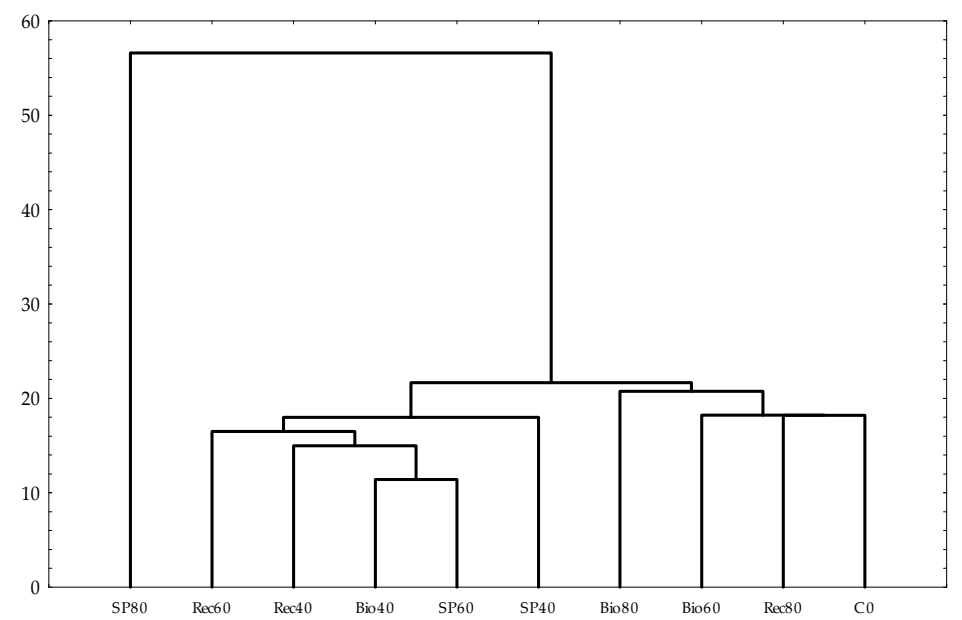

(b)

Figure 1. Heat map of operational taxonomic units (OTUs) in each experimental unit, classified at the class, order, family, genus, and species level (abbreviations are explained in Table 1). Red corresponds to high amount and green to low amount. Scale: $-0.4 \longrightarrow 5.6 \%$ OTUs, $0.1-5.7-12.6 \%$ OTUs, $0.6-12.7-27.6 \%$ OTUs, $1.1-27.7-49.8 \%$ OTUs, $1.6-49.9-58.0 \%$ OTUs, $2.1-58.1-68.2 \%$ OTUs, 2.6-68.3-93.6\% OTUs, and 3.1—<93.7\% OTUs. Dendrogram from hierarchical cluster analysis (Ward method using a dissimilarity matrix of Euclidean distances) on ln-transformed DNA-data of OTU 1 to OTU 10 combined for (a) fungi and (b) type of phosphorus fertilizers.

Table 8. Structure of fungal genera in wheat grain (percentage of OTUs).

\begin{tabular}{|c|c|c|c|c|c|c|c|c|c|c|c|c|c|c|}
\hline Phylum & Class & Order & Family & Genus & $\mathrm{CO}^{*}$ & SP40 & SP60 & SP80 & Rec40 & Rec60 & Rec80 & Bio40 & Bio60 & Bio80 \\
\hline \multirow{7}{*}{ Ascomycota } & \multirow{4}{*}{ Dothideomycetes } & \multirow{3}{*}{ Pleosporales } & \multirow{3}{*}{ Pleosporaceae } & Alternaria & 67.58 & 78.49 & 83.75 & 49.99 & 89.68 & 95.35 & 66.21 & 81.5 & 70.61 & 71.05 \\
\hline & & & & Bipolaris & 0 & 1,7 & 0 & 0 & 0 & 0 & 0 & 0 & 0 & 0 \\
\hline & & & & Stemphylium & 0 & 0 & 0 & 5.12 & 0 & 0 & 0 & 0 & 0 & 0 \\
\hline & & Capnodiales & Mycosphaerellaceae & Mycosphaerella & 2.15 & 1.22 & 1.49 & 1.64 & 1.11 & 0.61 & 5.58 & 0.66 & 1.01 & 8.23 \\
\hline & \multirow[b]{2}{*}{ Sordariomycetes } & Xylariales & Amphisphaeriaceae & Monographella & 11.97 & 0 & 1.82 & 4.17 & 0.88 & 0.27 & 7.14 & 2.57 & 2.85 & 0 \\
\hline & & Hypocreales & Nectriaceae & Gibberella & 1.6 & 1.22 & 0.94 & 4.5 & 3.06 & 0.62 & 2.9 & 0.62 & 4.45 & 5.49 \\
\hline & Leotiomycetes & Helotiales & Sclerotiniaceae & Botrytis & 0 & 0 & 0 & 0 & 0 & 0.08 & 0 & 0 & 0 & 0 \\
\hline \multirow{3}{*}{ Basidiomycota } & Tremellomycetes & Filobasidiales & Filobasidiaceae & Filobasidium & 0 & 0 & 0 & 0 & 0 & 0 & 0 & 0 & 0 & 0.19 \\
\hline & \multirow{2}{*}{ Ustilaginomycetes } & \multirow{2}{*}{ Ustilaginales } & \multirow{2}{*}{ Ustilaginaceae } & Ustilago & 0 & 0 & 0 & 0 & 0 & 0 & 0.41 & 0 & 0 & 0 \\
\hline & & & & Anthracocystis & 0.76 & 0 & 0.72 & 0 & 0.34 & 0.11 & 0 & 0 & 0 & 0 \\
\hline
\end{tabular}

The fungal community colonizing wheat grain from the treatment fertilized with superphosphate (clade 3, SP80) differed from the fungal communities identified in the remaining treatments (Figure 1). This difference was attributed to the lower amount of A. infectoria, sporadic appearance of Stemphylium herbarum, and higher amount of species of the family Nectriaceae. Fungal communities from the remaining treatments were grouped in two clades. Clade 1 was composed of fungal communities from treatments C0, Rec80, SP40, Bio60, and Bio 80, and clade 2 comprised fungal communities from treatments SP60, Rec40, Rec60, and Bio40. Clade 1 was characterized by a high frequency of $A$. infectoria and M. nivalis (C0, Rec80), and G. tricincta (Bio60, Bio80). The identified pathogens were less abundant in the communities forming clade 2. The method of next-generation sequencing in the Illumina MiSeq system allowed to identify of rare species and biotrophic fungi unable to grow on agar media.

The applied phosphorus fertilization modified the amount of fungal genera, as demonstrated by the PCA biplot (Figure 2). Treatments Rec40, Bio40, and Bio60 were grouped closest to the Tukey median (in the bagplot), and treatments SP60, SP80, Rec60, and Rec80 were located further away (in the bagplot cover region). An analysis of the PCA biplot revealed that the control treatment was separated 
by a significant distance from the Tukey median, and it was located in the opposite direction from treatments SP40 and Bio80.

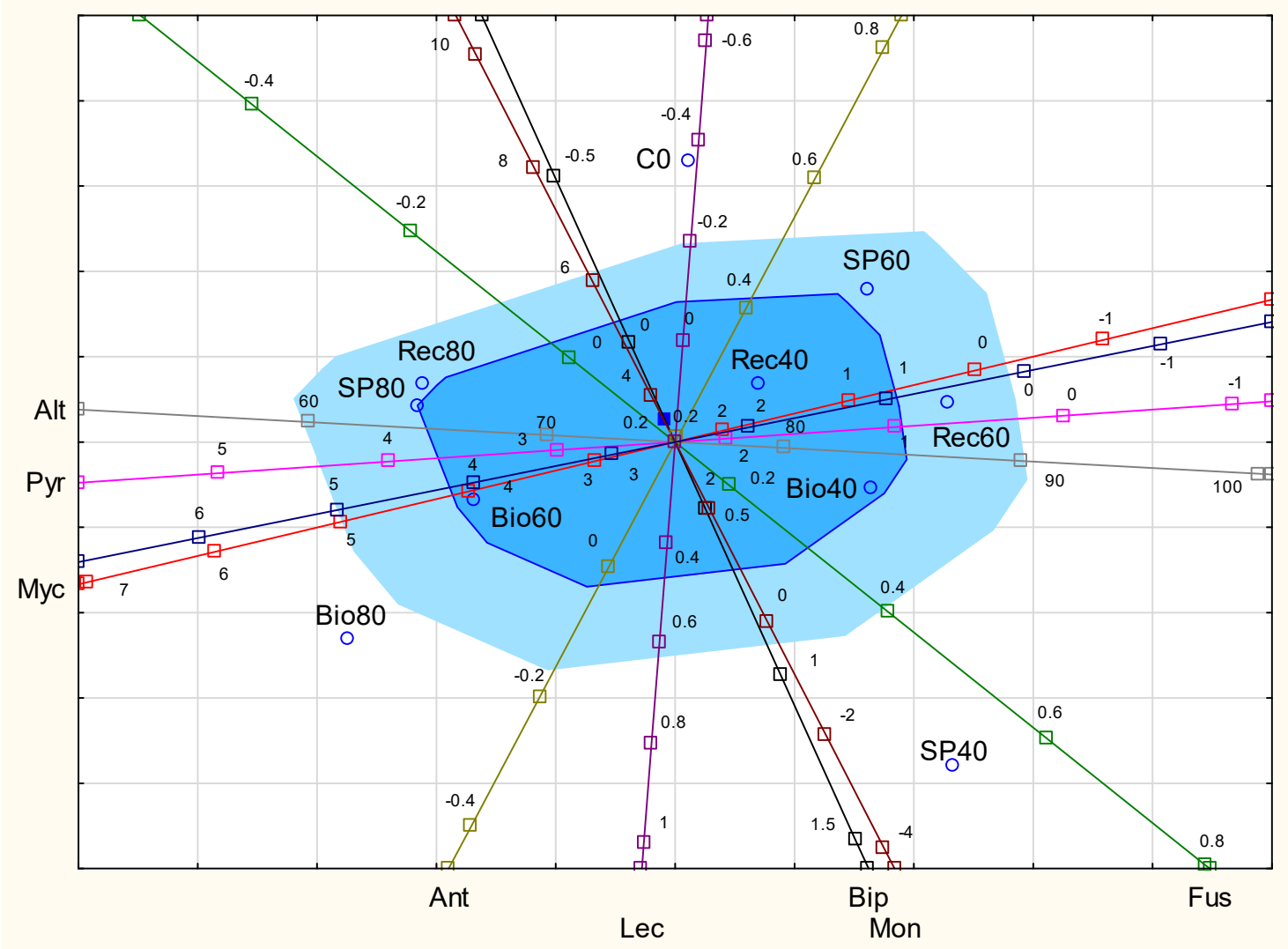

Figure 2. Principal component analysis (PCA) biplot of the microbiome in wheat grain based on fungal genera. The dark blue square denotes the Tukey median, the blue square is the bagplot, the light blue square is the bagplot cover. Alt-Alternaria spp., Pyr-Pyrenophora spp., Myc-Mycosphaerella spp., Ant-Anthracocystis spp., Lec-Lecanicillium spp., Bip-Bipolaris spp., Mon-Monographella spp., Fus-Fusarium spp.; C0, SP40, SP60, SP80, Rec40, Rec60, Rec80, Bio40, Bio60, Bio80-abbreviations are explained in Table 1.

\section{Discussion}

Although only a small percentage $(0.1-10 \%)$ of microorganisms can be grown on synthetic media in a laboratory, they can be predominant in the analyzed microbial communities $[44,45]$. The results of the culture-dependent method, as well as the modern high-throughput sequencing approach, indicate that wheat grain is an ecological niche which is colonized by relatively few fungal species with low amount [1]. The genera of filamentous fungi, Alternaria, Cladosporium, Epicoccum, Botrytis, and Fusarium, as well as yeast genera Cryptococcus and Sporobolomyces are characteristic of this environment [1,46,47]. In the present study, the co-existence patterns could be condensed into three distinct clusters of OTUs. Clade 1 was composed of fungal communities colonizing grain from non-fertilized plants and grain from plants supplied with the recycled biofertilizer with the addition of B. megaterium (Bio) bacteria at 60 and $80 \mathrm{P}_{2} \mathrm{O}_{5} \mathrm{ha}^{-1}$, recycled biofertilizer at $80 \mathrm{~kg} \mathrm{ha}^{-1}$ (Rec), and superphosphate (SP) at $40 \mathrm{~kg} \mathrm{ha}^{-1}$, and was characterized by higher counts of pathogenic species Monographella nivalis and G. tricincta, as well as species of the genera Pyrenophora and Mycosphaerella. Clade 3 comprised a fungal community colonizing grain from plants fertilized with the highest superphosphate rate $\left(80 \mathrm{~kg} \mathrm{ha}^{-1}\right)$, characterized by above-average proportions of pathogenic species of the genus Fusarium, unidentified species of the class Sordariomycetes, with the possible presence of the pathogenic genus Claviceps, and the saprotrophic species Stemphylium herbarum. Clade 2 grouped fungal communities colonizing grain 
from treatments with low and moderate fertilizer rates (Bio $40 \mathrm{~kg}$, Rec 40 and $60 \mathrm{~kg}$, and SP $60 \mathrm{~kg} \mathrm{P} \mathrm{P}_{2} \mathrm{O}_{5}$ $\mathrm{ha}^{-1}$ ). The fungal communities in clade 2 were characterized by a very high prevalence of $A$. infectoria, while the proportions of the remaining pathogens were low. In a study by Suproniene et al. [48], fungi of the genus Fusarium were more prevalent in wheat grain grown in non-fertilized treatments and treatments fertilized with a moderate rate of NPK than in grain from treatments fertilized with a high rate of NPK. According to the literature, nitrogen fertilization exerts a negative effect on the health status of wheat plants and contributes to grain colonization by pathogens. The above can be attributed mainly to changes in stand structure: fertilized stands are dense, and they retain more moisture, which promotes the growth and sporulation of pathogenic fungi [49]. Higher rates of nitrogen fertilizers also prolong flowering and plant maturation, and wheat is most susceptible to infections during flowering [49].

The influence of phosphorus fertilizers on plant health is significantly more complex. In a study by Karimzadeh et al. [50], wheat plants fertilized with phosphorus were characterized by higher root and above-ground biomass, higher chlorophyll and proline concentrations in tissues, as well as higher yields than plants not fertilized with this nutrient. Proline is an amino acid with a secondary amine that functions as an osmolyte during stress and plays a significant role in protecting plants against stress related to the infection process [51]. Phosphorus uptake by plants from soil is also modified by bacteria and soil moisture content [51]. In the work of Arif et al. [52], phosphorus uptake was significantly higher in soybean plants inoculated with Bacillus cereus GS6 than in control plants. In the present experiment, recycled phosphorus fertilizers were as effective sources of plant-available phosphorus in soil as superphosphate.

Phosphorus fertilizers probably enhanced plant growth and increased stand density, but they also promoted the production of compounds which increased wheat resistance against pathogens. However, the influence of the tested types of phosphorus fertilizers, including those containing B. megaterium that can act as PGPM [26], on the prevalence of pathogens in the field was sometimes ambiguous and modified by other factors. Similar results have never been reported in the literature, and further research is needed to explore these ambiguities.

In this study, wheat grain was mainly colonized by fungi of the genus Alternaria. High-throughput sequencing in the Illumina MiSeq system revealed that Alternaria fungi accounted for $45-95 \%$ of OTUs (subject to treatment). The colony counts of Alternaria grown on PDA ranged from 0.35 to $1.48 \log (\mathrm{CFU}+1)$ per $1 \mathrm{~g}$ of grain. Alternaria fungi were also isolated from $14.81-31.48 \%$ of wheat kernels plated on PDA. Dark colonies growing on PDA and the Martin medium were identified as A. alternata, and similar observations were made by other authors [46,47]. Alternaria alternata is a ubiquitous saprotroph which infects cereal spikes and causes black scab and black point disease in cereals [53]. The species produces more than 10 allergizing proteins (www.allergen.org). The most frequently described protein Alt a 1 (AAM90320.1. NCBI. Protein Database [54] has been linked with asthma. Alt a 1 is a glycoprotein with a molecular mass of $29 \mathrm{kDa}$. Alternaria alternata also produces around 70 secondary metabolites, including mycotoxins that are potentially dangerous for humans and animals [55].

In traditional analyses of the plant microbiome, microorganisms are isolated and cultured on various media with the use of different methods. However, microbial communities isolated from wheat by culture-dependent methods are characterized by lower diversity than those detected with the use of culture-independent molecular techniques [53]. In the present study, a higher number of pathogenic fungi, in particular pathogens of the genus Ustilago, were obtained by next-generation sequencing in the Illumina MiSeq system. Ustilago tritici causes loose smut which is widely distributed with grain and can decrease wheat yields by up to $40 \%$. The disease is particularly dangerous for seed farms and undressed grain [56].

In the current study, several pathogenic species that are sporadically carried by wheat grain or are less frequently isolated from grain were obtained with the use of culture-dependent methods. Rhizoctonia cerealis, a fungus which causes sharp eyespot, was first identified in Poland in the late 
1990s [57]. Pyrenophora tritici-repentis, the causal agent of tan spot, was isolated from $21.31 \%$ of kernels by Bankina et al. [46]. Next-generation sequencing also supported the identification of the slow-growing pathogen M. nivalis which is not detected with the use of culture-dependent methods. Kernels infected with M. nivalis and Fusarium species are characterized by lower plumpness and pink discoloration. Fusarium fungi can cause head blight and stalk rot when distributed with infected grain. Fusarium fungi obtained by the culture-dependent method in this study are characteristic of the cooler regions of north-eastern Europe and Canada, and F. culmorum was the predominant species [3]. Fusarium graminearum is most prevalent in warmer, humid areas of the world such as North America, Europe, and South America [58], and it was also relatively frequently isolated in this study. The growing season of 2016 was characterized by favorable weather conditions for the growth of spring wheat, but high precipitation during grain setting and filling (total precipitation in July was $71 \%$ higher than the long-term average) delayed ripening. The above contributed to the spread of infections caused by Fusarium fungi.

Fungi colonizing crops can exert both positive and negative effects on the growth of host plants. The former include secreting plant growth hormones and producing compounds that inhibit the development of pathogens and increase plant resistance to infections $[59,60]$. In the current study, the cultured yeast communities were not significantly influenced by the tested fertilizers. The authors' previous research demonstrated that yeasts inhibit the development of Fusarium pathogens [3].

High-throughput sequencing in the Illumina MiSeq system supports more detailed analyses of the structure and diversity of microbial communities than conventional isolation techniques. Fungi respond more rapidly to environmental changes than other living organisms [61,62], and changes in the structure and diversity of microbial communities influence plant health. In this study, the structure and diversity of fungal communities colonizing spring wheat grain were influenced by changes in soil P content caused by the tested fertilizers. However, the observed changes were determined mainly by the P-rate rather than fertilizer type. The highest rate of commercial fertilizer induced the most adverse changes in the balance between pathogenic and non-pathogenic fungi. In a study by Eschen et al. [61], the composition of endophytic fungal communities colonizing the leaves and stems of Cirsium arvense varied subject to soil $\mathrm{P}$ content. The above authors attributed these changes to differences in fungal species' demand for leaf nutrients which can be affected by the availability of soil nutrients. Pellissier et al. [62] analyzed the composition of fungal communities in grain dust and aerosols released during wheat harvest and did not report significant correlations between total soil P and the taxonomic and phylogenetic beta diversity of fungi.

\section{Conclusions}

Recycled phosphorus fertilizers can at least partly replace commercial fertilizers in wheat production. They are less abundant in phosphorus than commercial mineral fertilizers, but they contain numerous macronutrients and micronutrients. Lower rates of recycled phosphorus fertilizers are adequate sources of plant-available phosphorus in soil, and they exert a beneficial impact on the structure of fungal communities colonizing the grain. Wheat grain from the treatments supplied with recycled fertilizer at 40 and $60 \mathrm{~kg} \mathrm{P}_{2} \mathrm{O}_{5} \mathrm{ha}^{-1}$ and the B. megaterium biofertilizer at $40 \mathrm{~kg} \mathrm{P}_{2} \mathrm{O}_{5} \mathrm{ha}^{-1}$, was colonized by fungal communities with the most desirable composition and the lowest proportion of plant pathogens. However, the influence of recycled fertilizers on the physiology of field-grown plants and possible interactions with other environmental factors have not been fully elucidated and require further research.

Author Contributions: Conceptualization, M.J., U.W. and M.K.K.; methodology, M.J. and U.W.; formal analysis, U.W.; investigation, M.J., U.W. and M.K.K.; resources, M.J., U.W. and M.K.K.; writing-original draft preparation, U.W. and M.J.; writing - review and editing, M.J. and M.K.K.; visualization, M.J. and U.W.; funding acquisition, M.J. and M.K.K. All authors have read and agree to the published version of the manuscript.

Funding: This research was funded by the National Center for Research and Development, Poland, grant number PBS 2/A1/11/2013. 
Acknowledgments: The Institute of New Chemical Synthesis in Puławy is highly acknowledged for providing Rec and Bio-fertilizers for the field experiment. The authors kindly acknowledge the technical support of Kinga Treder and Przemysław Makowski from the University of Warmia and Mazury in Olsztyn.

Conflicts of Interest: The authors declare no conflict of interest.

\section{References}

1. Nicolaisen, M.; Justesen, A.F.; Knorr, K.; Wang, J.; Pinnschmidt, H.O. Fungal communities in wheat grain show significant co-existence patterns among species. Fungal Ecol. 2014, 11, 145-153. [CrossRef]

2. Larran, S.; Perelló, A.; Simón, M.R.; Moreno, V. The endophytic fungi from wheat (Triticum aestivum L.). World J. Microbiol. Biotechnol. 2007, 23, 565-572. [CrossRef]

3. Wachowska, U.; Waśkiewicz, A.; Jedryczka, M. Using a protective treatment to reduce Fusarium pathogens and mycotoxins contaminating winter wheat grain. Pol. J. Environ. Stud. 2017, 26, 2277-2286. [CrossRef]

4. Wang, X.; Wang, C.; Sui, J.; Liu, Z.; Li, Q.; Ji, C.; Song, X.; Hu, Y.; Wang, C.; Sa, R. Isolation and characterization of phosphofungi, and screening of their plant growth-promoting activities. AMB Express 2018, 8, 63. [CrossRef] [PubMed]

5. Hassegawa, R.H.; Fonseca, H.; Fancelli, A.L.; da Silva, V.N.; Schammass, E.A.; Reis, T.A.; Corrêa, B. Influence of macro- and micronutrient fertilization on fungal contamination and fumonisin production in corn grains. Food Control 2008, 19, 36-43. [CrossRef]

6. Wachowska, U.; Stasiulewicz-Paluch, A.D.; Głowacka, K.; Mikołajczyk, W.; Kucharska, K. Response of epiphytes and endophytes isolated from winter wheat grain to biotechnological and fungicidal treatments. Pol. J. Environ. Stud. 2013, 22, 267-273.

7. Taghinasab, M.; Imani, J.; Steffens, D.; Glaeser, S.P.; Kogel, K.H. The root endophytes Trametes versicolor and Piriformospora indica increase grain yield and P content in wheat. Plant Soil 2018, 426, 339-348. [CrossRef]

8. Grzebisz, W.; Potarzycki, J.; Biber, M.; Szczepaniak, W. Reakcja roślin uprawnych na nawożenie fosforem. J. Elem. 2003, 8, 83-93.

9. Haneklaus, S.H.; Schnug, E. Assessing the plant phosphorus status. In Phosphorus in Agriculture: $100 \%$ Zero; Springer: Dordrecht, The Netherlands, 2016; pp. 95-125.

10. Prabhu, A.S.; Fageria, N.K.; Berni, R.F.; Rodrigues, F.A. Phosphorus and plant disease. In Mineral Nutrition and Plant Disease; American Phytopathological Society: St. Paul, MN, USA, 2007; pp. 45-55.

11. Mohammadi, K. Phosphorus solubilizing bacteria: Occurrence, mechanisms and their role in crop production. Resour. Environ. 2012, 2, 80-85.

12. Weigand, H.; Bertau, M.; Hübner, W.; Bohndick, F.; Bruckert, A. RecoPhos: Full-scale fertilizer production from sewage sludge ash. Waste Manag. 2013, 33, 540-544. [CrossRef]

13. Van Kauwenbergh, S.J.; Stewart, M.; Mikkelsen, R. World reserves of phosphate rock ... a dynamic and unfolding story. Better Crops 2013, 97, 18-20.

14. Tenkorang, F.; Lowenberg-Deboer, J. Forecasting long-term global fertilizer demand. Nutr. Cycl. Agroecosyst. 2009, 83, 233-247. [CrossRef]

15. Cordell, D.; White, S. Peak phosphorus: Clarifying the key issues of a vigorous debate about long-term phosphorus security. Sustainability 2011, 3, 2027-2049. [CrossRef]

16. Schroder, J.J.; Cordell, D.; Smit, A.L.; Rosemarin, A. Sustainable use of Phosphorus: EU Tender ENV. B1/ETU/2009/0025; Plant Research International: Wageningen, The Netherlands, 2010.

17. Rosemarin, A.; Jensen, L.S. The phosphorus challenge. In Proceedings of the European Sustainable Phosphorus Conference, Brussels, Belgium, 6-7 March 2013.

18. USGS. Mineral Commodity Summaries 2019. Phosphate Rock; U.S. Geological Survey: Reston, VA, USA, 2019; pp. 122-123.

19. Geissler, B.; Mew, M.C.; Steiner, G. Phosphate supply security for importing countries: Developments and the current situation. Sci. Total Environ. 2019, 677, 511-523. [CrossRef]

20. EC. Report on critical raw materials for the EU. European Commission. In Report of the Ad-Hoc Working Group on Defining Critical Raw Materials; EC: Brussels, Belgium, 2014; p. 41.

21. Jaskulski, D.; Jaskulska, I. Possibility of using waste from the polyvinyl chloride production process for plant fertilization. Pol. J. Environ. Stud. 2011, 20, 351-354. 
22. Smol, M.; Kulczycka, J.; Kowalski, Z. Sewage sludge ash (SSA) from large and small incineration plants as a potential source of phosphorus-Polish case study. J. Environ. Manag. 2016, 184, 617-628. [CrossRef]

23. Staron, A.; Kowalski, Z.; Banach, M.; Wzorek, Z. Sposoby termicznej utylizacji odpadów z przemysłu mięsnego. Czas. Tech. Chem. 2010, 107, 323-332.

24. Saeid, A.; Labuda, M.; Chojnacka, K.; Górecki, H. Use of microorganisms in the production of phosphorus fertilizers. Przem. Chem. 2012, 91, 956-958.

25. Karpagam, T.; Nagalakshmi, P.K. Isolation and characterization of phosphate solubilizing microbes from agricultural soil. Int. J. Curr. Microbiol. Appl. Sci. 2014, 3, 601-614.

26. Awasthi, R.; Tewari, R.; Nayyar, H. Synergy between plants and P-solubilizing microbes in soils: Effects on growth and physiology of crops. Int. Res. J. Microbiol. 2011, 2, 484-503.

27. El-Komy, H.M.A. Coimmobilization of Azospirillum lipoferum and Bacillus megaterium for successful phosphorus and nitrogen nutrition of wheat plants. Food Technol. Biotechnol. 2005, 43, $19-27$.

28. Saeid, A.; Prochownik, E.; Dobrowolska-Iwanek, J. Phosphorus solubilization by Bacillus species. Molecules 2018, 23. [CrossRef] [PubMed]

29. Etesami, H.; Beattie, G.A. Mining halophytes for plant growth-promoting halotolerant bacteria to enhance the salinity tolerance of non-halophytic crops. Front. Microbiol. 2018, 9. [CrossRef] [PubMed]

30. Nesme, T.; Withers, P.J.A. Sustainable strategies towards a phosphorus circular economy. Nutr. Cycl. Agroecosys. 2016, 104, 259-264. [CrossRef]

31. Saeid, A.; Wyciszkiewicz, M.; Jastrzebska, M.; Chojnacka, K.; Gorecki, H. A concept of production of new generation of phosphorus-containing biofertilizers. BioFertP project. Przem. Chem. 2015, 94, 361-365. [CrossRef]

32. Rolewicz, M.; Rusek, P.; Borowik, K. Obtaining of granular fertilizers based on ashes from combustion of waste residues and ground bones using phosphorous solubilization by bacteria Bacillus megaterium. J. Environ. Manag. 2018, 216, 128-132. [CrossRef]

33. Meier, U. Growth Stages of Mono- and Dicotyledonous Plants: BBCH-Monograph; Blackwell Wissenschafts-Verlag: Berlin, Germany; Boston, MA, USA, 1997; p. 622.

34. World Reference Base (WRB); IUSS Working Group. World reference base for soil resources 2014. In International Soil Classification System for Naming Soils and Creating Legends for Soil Maps; Food and Agriculture Organization of the United Nations: Rome, Italy, 2014; update 2015.

35. Martin, J.P. Use of acid, rose bengal, and streptomycin in the plate method for estimating soil fungi. Soil Sci. 1950, 69, 215-232. [CrossRef]

36. Ellis, M.B. Dematiaceous Hyphomycetes; CMI: Kew, UK, 1971; p. 608.

37. Leslie, J.F.; Summerell, B.A. The Fusarium Laboratory Manual; Blackwell Publishing: Hoboken, NJ, USA, 2007; pp. $1-388$.

38. Caporaso, J.G.; Kuczynski, J.; Stombaugh, J.; Bittinger, K.; Bushman, F.D.; Costello, E.K.; Fierer, N.; Pẽa, A.G.; Goodrich, J.K.; Gordon, J.I.; et al. QIIME allows analysis of high-throughput community sequencing data. Nat. Methods 2010, 7, 335-336. [CrossRef]

39. Edgar, R.C. Search and clustering orders of magnitude faster than BLAST. Bioinformatics 2010, 26, $2460-2461$. [CrossRef]

40. Nilsson, R.H.; Larsson, K.H.; Taylor, A.F.S.; Bengtsson-Palme, J.; Jeppesen, T.S.; Schigel, D.; Kennedy, P.; Picard, K.; Glöckner, F.O.; Tedersoo, L.; et al. The UNITE database for molecular identification of fungi: Handling dark taxa and parallel taxonomic classifications. Nucleic Acids Res. 2019, 47, D259-D264. [CrossRef]

41. StatSoft, I. Statistica (Data Analysis Software System), Version 13; Statsoft Inc.: Tulsa, OK, USA, 2016.

42. Wilkinson, L.; Friendly, M. History corner the history of the cluster heat map. Am. Stat. 2009, 63, $179-184$. [CrossRef]

43. Ward, J.H., Jr. Hierarchical grouping to optimize an objective function. J. Am. Stat. Assoc. 1963, 58, $236-244$. [CrossRef]

44. Ellis, R.J.; Morgan, P.; Weightman, A.J.; Fry, J.C. Cultivation-dependent and -independent approaches for determining bacterial diversity in heavy-metal-contaminated soil. Appl. Environ. Microbiol. 2003, 69, 3223-3230. [CrossRef] [PubMed]

45. Littlefield-Wyer, J.G.; Brooks, P.; Katouli, M. Application of biochemical fingerprinting and fatty acid methyl ester profiling to assess the effect of the pesticide Atradex on aquatic microbial communities. Environ. Pollut. 2008, 153, 393-400. [CrossRef] [PubMed] 
46. Bankina, B.; Bimšteine, G.; Neusa-Luca, I.; Roga, A.; Fridmanis, D. What influences the composition of fungi in wheat grains? Acta Agrobot. 2017, 70. [CrossRef]

47. Xu, K.G.; Jiang, Y.M.; Li, Y.K.; Xu, Q.Q.; Niu, J.S.; Zhu, X.X.; Li, Q.Y. Identification and pathogenicity of fungal pathogens causing black point in wheat on the North China Plain. Indian J. Microbiol. 2018, 58, 159-164. [CrossRef] [PubMed]

48. Suproniene, S.; Mankevičiene, A.; Kadžiene, G.; Kačergius, A.; Feiza, V.; Feiziene, D.; Semaškiene, R.; Dabkevičius, Z.; Tamošiunas, K. The impact of tillage and fertilization on Fusarium infection and mycotoxin production in wheat grains skaidre suproniene. Zemdirbyste 2012, 99, 265-272.

49. Lemmens, M.; Haim, K.; Lew, H.; Ruckenbauer, P. The effect of nitrogen fertilization on Fusarium head blight development and deoxynivalenol contamination in wheat. J. Phytopathol. 2004, 152, 1-8. [CrossRef]

50. Karimzadeh, J.; Alikhani, H.A.; Etesami, H.; Pourbabaei, A.A. Improved phosphorus uptake by wheat plant (Triticum aestivum L.) with rhizosphere fluorescent Pseudomonads strains under water-deficit stress. J. Plant Growth Regul. 2020. [CrossRef]

51. Zhang, X.; Ervin, E.H.; Evanylo, G.K.; Haering, K.C. Impact of biosolids on hormone metabolism in drought-stressed tall fescue. Crop Sci. 2009, 49, 1893-1901. [CrossRef]

52. Arif, M.S.; Riaz, M.; Shahzad, S.M.; Yasmeen, T.; Ali, S.; Akhtar, M.J. Phosphorus-mobilizing rhizobacterial strain Bacillus cereus GS6 improves symbiotic efficiency of soybean on an aridisol amended with phosphorus-enriched compost. Pedosphere 2017, 27, 1049-1061. [CrossRef]

53. Wang, J.; Qin, J.; Li, Y.; Cai, Z.; Li, S.; Zhu, J.; Zhang, F.; Liang, S.; Zhang, W.; Guan, Y.; et al. A metagenome-wide association study of gut microbiota in type 2 diabetes. Nature 2012, 490, 55-60. [CrossRef]

54. Protein Database. National Center for Biotechnology Information. Proteins. U.S. National Library of Medicine. Available online: https://www.ncbi.nlm.nih.gov/protein (accessed on 7 July 2018).

55. Jarolim, K.; Del Favero, G.; Pahlke, G.; Dostal, V.; Zimmermann, K.; Heiss, E.; Ellmer, D.; Stark, T.D.; Hofmann, T.; Marko, D. Activation of the Nrf2-ARE pathway by the Alternaria alternata mycotoxins altertoxin I and II. Arch. Toxicol. 2017, 91, 203-216. [CrossRef] [PubMed]

56. Menzies, J.G. Virulence of isolates of Ustilago tritici collected in Manitoba and Saskatchewan, Canada, from 1999 to 2007. Can. J. Plant Pathol. 2016, 38, 470-475. [CrossRef]

57. Mikolajska, J.; Wachowska, U. Characterization of binucleate isolates of Rhizoctonia cerealis with respect to cereals. In Proceedings of the Symposium on New Direction in Plant Pathology, Kraków, Poland, 11-13 September 1996.

58. Weidenbörner, M. Mycotoxin contamination of cereals and cereal products. In Mycotoxins in Plants and Plant Products; Springer: Berlin/Heidelberg, Germany, 2017; pp. 1-715.

59. Lakshmanan, V.; Selvaraj, G.; Bais, H.P. Functional soil microbiome: Belowground solutions to an aboveground problem. Plant Physiol. 2014, 166, 689-700. [CrossRef]

60. Berendsen, R.L.; Pieterse, C.M.J.; Bakker, P.A.H.M. The rhizosphere microbiome and plant health. Trends Plant Sci. 2012, 17, 478-486. [CrossRef]

61. Eschen, R.; Hunt, S.; Mykura, C.; Gange, A.C.; Sutton, B.C. The foliar endophytic fungal community composition in Cirsium arvense is affected by mycorrhizal colonization and soil nutrient content. Fungal Biol. 2010, 114, 991-998. [CrossRef]

62. Pellissier, L.; Oppliger, A.; Hirzel, A.H.; Savova-Bianchi, D.; Mbayo, G.; Mascher, F.; Kellenberger, S.; Niculita-Hirzel, H. Airborne and grain dust fungal community compositions are shaped regionally by plant genotypes and farming practices. Appl. Environ. Microbiol. 2016, 82, 2121-2131. [CrossRef]

(C) 2020 by the authors. Licensee MDPI, Basel, Switzerland. This article is an open access article distributed under the terms and conditions of the Creative Commons Attribution (CC BY) license (http://creativecommons.org/licenses/by/4.0/). 